\title{
Getting the Most out of Social Media: Successfully Using Social Media ${ }^{1}$
}

\author{
Lauri M. Baker, Caroline R. Warwick, Jessica C. Fernandez, and Joy N. Rumble²
}

\section{Introduction: Understanding Social Media}

With the majority of Americans saying they get their news from social media (Shearer \& Mitchell, 2021), the internet is a crucial tool for those in the agricultural industry trying to spread information to consumers. During the COVID-19 pandemic Americans turned to technology, including social media, for work, school, and social aspects of their lives (Anderson \& Vogels, 2020). Additionally, social media can offer a way for public agencies, like Extension, to connect with their stakeholders (Cockerill, 2013).

This EDIS publication is written for Florida agriculturalists, Extension agents, agricultural organizations and other individuals interested in successfully using social media to connect with their stakeholders, potential customers or other individuals. This publication focuses on describing successful ways in which an organization can use social media and getting the most out of their social media usage.

\section{What Does Using Social Media Achieve?}

Social media's primary purpose is to exchange information with a target audience- the individuals you want your information to reach-for example, consumers. On all social media platforms, information is uploaded, commented on, and shared. In sharing information, agriculturalists should focus on four areas (Figure 1):

1. Building Relationships: Is the information you are sharing on social media platform(s) building a relationship with your stakeholders or customers? The value of social media above other media is the ability to exchange information back and forth and build a relationship with followers (Stebner et al., 2017).

2.Influencing: Is the information you are posting on your social media platform(s) encouraging members of your target audience to seek correct and accurate information so that they make more informed decisions when purchasing agricultural product(s)? Social media has the capacity to influence purchasing decisions of followers (Baker et al., 2020).

3. Educating: Is the information you are posting on your social media platform(s) teaching and informing the target audience about agricultural commodities, industry, or history? Education is an important aspect of social media for agricultural businesses and their customers (Stebner et al., 2017).

1. This document is AEC560, one of a series of the Department of Agricultural Education and Communication, UF/IFAS Extension. Original publication date August 2015. Revised July 2021. Visit the EDIS website at https://edis.ifas.ufl.edu for the currently supported version of this publication.

2. Lauri M. Baker, associate professor, Department of Agricultural Education and Communication; Caroline R. Warwick, science communication specialist, UF/IFAS Mid-Florida Research and Education Center, Apopka, FL; Jessica C. Fernandez, former graduate student, Department of Agricultural Education and Communication; and Joy Rumble, former assistant professor, Department of Agricultural Education and Communication, UF/IFAS Center for Public Issues Education in Agriculture and Natural Resources; UF/IFAS Extension, Gainesville, FL 32611.

The Institute of Food and Agricultural Sciences (IFAS) is an Equal Opportunity Institution authorized to provide research, educational information and other services

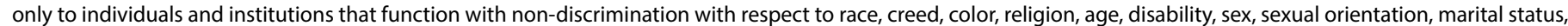

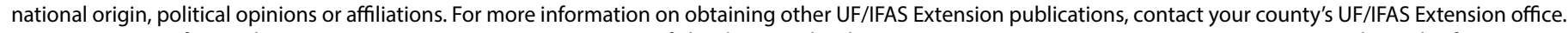
U.S. Department of Agriculture, UF/IFAS Extension Service, University of Florida, IFAS, Florida A \& M University Cooperative Extension Program, and Boards of County Commissioners Cooperating. Nick T. Place, dean for UF/IFAS Extension. 
4. Branding: Is the information you are posting on your social media platform(s) promoting your brand or the agricultural industry as a whole in an open and honest manner that will prompt your target audience to seek out your products? Building an effective brand for your business or Extension program is possible through a solid, intentional social media strategy (Zagonel et al., 2019).

\section{Presence: Are you present on social media? Are you} utilizing social media as a cost effective and savvy way of marketing your agricultural business and industry to the public? One important aspect of social media for agricultural businesses is having an active, online presence (Peterson et al., 2018).

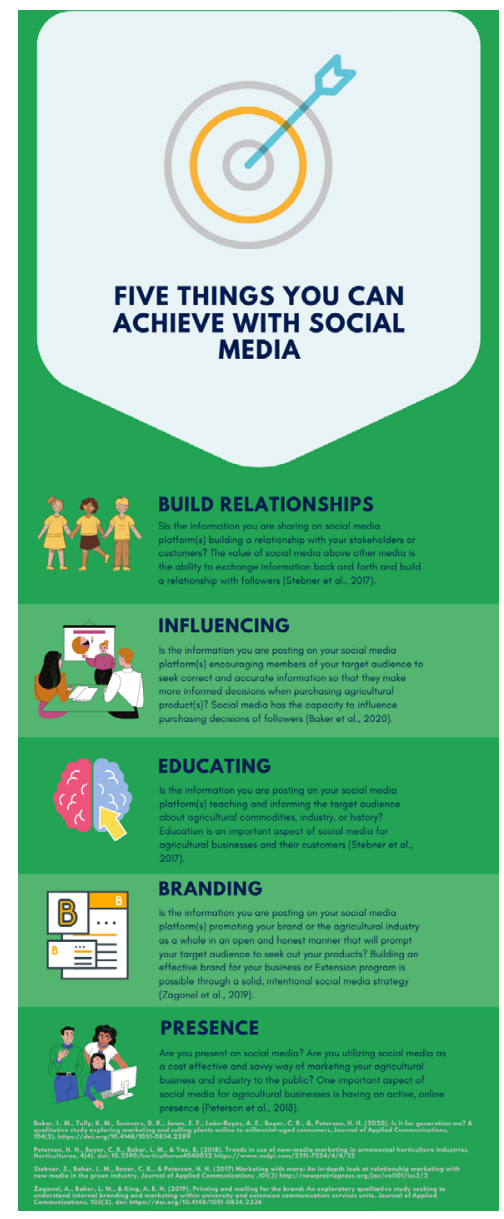

Figure 1. Using Social Media to Achieve Your Goals. Credits: Lauri M. Baker

\section{How Do You Achieve Success in These Four Areas?}

As an agriculturalist and information provider, you have the power to influence consumer behavior. You are able to prompt awareness, spread information, influence opinions, attitudes, and purchasing behavior, through the information you provide to consumers. Social media also lets agricultural businesses listen to, interact with, and seek feedback from customers (Cockerill, 2013). These interactions result in beneficial relations between agricultural businesses and consumers alike (Cockerill, 2013).

In order to be successful on social media, an agricultural business must evaluate and determine who, what, where, and how it wants to share information with consumers. Before starting to use social media platforms, asking the following questions can help:

1. Who is/are the target audience(s)?

2. Which traditional and social media platforms does/do the target audience(s) use?

3. What marketing content (story) does the farm want to tell?

4. How can marketing through social media promote or connect this content previously used marketing techniques (if applicable)?

These questions can help lay out a plan that agriculturalists can use to connect with their consumers and embrace the transformation social media has had on the internet and the spread of information. For help on understanding what platforms your audience uses and their needs for social media, you can explore data from Pew Research on American social media trends (Perrin \& Anderson, 2019).

\section{Are You Using Social Media Successfully?}

Agriculturalists who use social media successfully should eventually observe a higher level of public trust and loyalty between industry and consumers. At the moment, however, there are a few ways you can measure if you are successful on social media, including (DeStefano, 2015):

1. Reach: How many people did you impact with the content you have shared? You can track this, for example, by the number of followers you have on Twitter, the number of likes your Facebook page has, or number of views and subscribers to your YouTube channel.

2. Engagement: How many people interacted with the content you shared? You can track this, for example, by the number of clicks on your social media posts; retweets, mentions, and direct messages on Twitter; shares on Facebook; and ratings on YouTube channels. 
3. Conversion: How many people took action because of the content that you shared? You can track this, for example, by the number of online sales, attendance to events promoted through social media, or increase of in-store sales.

\section{Summary}

As audiences continue to use online information and sources to improve their lives and learn about the world around them, it is increasingly important for all business, including agricultural businesses, to have a strong presence online. Interacting on social media platforms is a significant way in which this can occur.

For more information on getting the most out of social media, be sure to check out these other publications from faculty housed in the UF/IFAS Center for Public Issues Education in Agriculture and Natural Resources:

- Getting the Most out of Social Media: What is Social Media?

- Getting the Most out of Social Media: How to Successfully Use Social Media

- Getting the Most out of Social Media: Good Practices When Using Social Media

- Storytelling through Social Media (AEC 556)

- Story Development (AEC 553)

- Face-to-Face Storytelling (AEC 555)

- Letting Them In: Sharing Your Story with People outside of Your Industry (AEC 554)

\section{References}

Anderson, M. \& Vogels, E. (2020). Americans turn to technology during COVID-19 outbreak, say an outage would be a problem. FactTank News in The Numbers. https://www.pewresearch.org/fact-tank/2020/03/31/ americans-turn-to-technology-during-covid-19-outbreaksay-an-outage-would-be-a-problem

Baker, L. M., Tully, K. M., Sumners, D. R., Jones, E. F., LeónReyes, A. E., Boyer, C. R., \&, Peterson, H. H. (2020). Is it for generation me? A qualitative study exploring marketing and selling plants online to millennial-aged consumers, Journal of Applied Communications, 104(2). https://doi. org/10.4148/1051-0834.2289
Cockerill, C. (2013). Exploring social media obstacles and opportunities within public agencies: Lessons from the Ohio Division of Wildlife. International Journal of Business and Social Sciences, 4(2): 39-44.

DeStefano, B. (2015). How to measure social media marketing success. Online Marketing Resources. Retrieved from http://www.svmsolutions.com/resources/articles/ how-measure-social-media-marketing-success

Perrin, A. \& Anderson, M. (2019). Share of U.S. adults using social media, including Facebook, is mostly unchanged since 2018. Pew Research Center. FactTank News in The Numbers. https://www.pewresearch.org/fact$\operatorname{tank} / 2019 / 04 / 10 /$ share-of-u-s-adults-using-social-mediaincluding-facebook-is-mostly-unchanged-since-2018

Peterson, H. H., Boyer, C. R., Baker, L. M., \& Yao, B. (2018). Trends in use of new-media marketing in ornamental horticulture industries. Horticulturae, 4(4). doi: 10.3390/horticulturae4040032 https://www.mdpi.com/2311-7524/4/4/32

Shearer, E. \& Mitchell, A. (2021). News Use Across Social Media Platforms in 2020: Facebook stands out as a regular source of news for about a third of Americans. Pew Research Center. https://www.journalism.org/2021/01/12/ news-use-across-social-media-platforms-in-2020

Stebner, S., Baker, L. M., Boyer, C. R., \& Peterson, H. H. (2017) Marketing with more: An in-depth look at relationship marketing with new media in the green industry, Journal of Applied Communications, 101(2) http://newprairiepress.org/jac/vol101/iss2/2

Telg, R., \& Irani, T. (2012). Agricultural communications in action: A hands-on approach (1st ed.). Clifton Park, NY: Delmar, CENGAGE Learning.

Zagonel, A., Baker, L. M., \& King, A. E. H. (2019). Printing and mailing for the brand: An exploratory qualitative study seeking to understand internal branding and marketing within university and extension communication services units. Journal of Applied Communications, 103(2). doi: https://doi.org/10.4148/1051-0834.2236 